\title{
A Different Approach to the Reconstruction of the Stubborn Crooked Nose with a Different Spreader Graft: Nasal Bone Grafts Harvested from the Removed Nasal Hump
}

\author{
I. M. Emsen
}

Published online: 2 July 2009

(C) Springer Science+Business Media, LLC and International Society of Aesthetic Plastic Surgery 2009

Retraction to: Aesth Plast Surg (2008) 32:266-273

DOI 10.1007/s00266-007-9108-4

This article was retracted by the Editor-in-Chief as portions of it were originally published by A. Gurlek et al., Correction of the Crooked Nose Using Custom-Made High-Density Porous Polythylene Extended Spreader Grafts. Aesth Plast Surg 30:141-149.

The online version of the original article can be found under doi:10.1007/s00266-007-9108-4.

I. M. Emsen $(\bowtie)$

Department of Plastic Reconstructive and Aesthetic Surgery,

Numune State Hospital, Numune Hastanesi, Plastik Cerrahi

Klinii, Erzurum 25240, Turkey

e-mail: ilterisemsen@hotmail.com; iemsen@yahoo.com 